\title{
Combination of 2-oxoglutarate/ascorbic acid/5-hydroxy- methyl-furfur-aldehyde/carnosine inhibits protein oxidation during radical exposure of cigarette smoke
}

\author{
Joachim F. Greilberger ${ }^{1,2}$, Reinhold Wintersteiger ${ }^{3}$, Ortner Astrid ${ }^{3}$, Michaela Greilberger ${ }^{2}$ and Ralf Herwig $^{4,5 *}$ \\ ${ }^{1}$ Institute for Physiological Chemistry, Centre for Medical Physiology, Medical University Graz, Graz, Austria \\ ${ }^{2}$ Institute of Scientific Laboratory Dr. Greilberger GmbH, Schwarzl Medical Center, Lassnitzhoehe/Graz, Austria \\ ${ }^{3}$ Institute of Pharmaceutical Sciences, University of Graz, Austria \\ ${ }^{4}$ Department of Urology, German Medical Center, Dubai \\ ${ }^{5}$ Men's Health Clinic, Vienna, Austria
}

\begin{abstract}
Exposure to cigarette smoke increase the formation of oxidatively modified proteins, lipids, DNA/RNA and carbohydrates in humans. These toxic substances are involved in several pathologies such as, e.g., cancer. Antioxidative supplementation is known to decrease the formation of oxidatively modified proteins, namely, carbonyl proteins. A newly developed combination of 2-oxoglutarate/ascorbic acid/5-hydroxy-methyl-furfur-aldehyde/carnosine was estimated as to the protection of generated carbonyl proteins in vivo and in vitro.

Methods: Carbonyl protein content in human plasma of 15 smokers and 15 non-smokers were estimated with the Carbonylprotein ELISA, and in erythrocyte proteins with the spectro-photometically method. 15 smokers were randomly assigned to drink the combination of 2-oxoglutarate/ascorbic acid/5-hydroxy-methylfurfur-aldehyde over 4 weeks. Plasma carbonyl proteins were measured before and after 2 and 4 weeks of supplementation.

In vitro studies of cigarette smoke modified proteins in absence or presence of the combination of 2-oxoglutarate/ascorbic acid/5-hydroxy-methyl-furfur-aldehyde/ carnosine or the separate substances 2-oxoglutarate, ascorbic acid, and 5-hydroxy-methyl-furfur-aldehyde were measured with the carbonyl protein spectrophotometically method before, after 2, 15 and 30 minutes.

Results: Carbonyl protein in plasma was significantly higher in smokers $(448 \pm 223 \mathrm{pmol} / \mathrm{mg})$ as compared to non-smokers $(191 \pm 40 \mathrm{pmol} / \mathrm{mg}$; $<<0.02)$, highly significant in erythrocyte proteins $(26.8 \pm 12.9 \mathrm{nmol} / \mathrm{mg}$ vs. $12.1 \pm 0.3 \mathrm{nmol} / \mathrm{mg} ; \mathrm{p}<0.001)$. After 4 weeks the supplemented group showed significant lower carbonyl proteins $(228 \pm 11 \mathrm{pmol} / \mathrm{mg})$ as compared to the non-supplemented $(325 \pm 45 \mathrm{pmol} / \mathrm{mg} ; \mathrm{p}<0.001)$.

In vitro, smoking of BSA solution showed a significant reduction of generated carbonyl proteins in the presence of the combined supplements after 2 min. ( $2.18 \pm 0.34$ $\mathrm{nmol} / \mathrm{mg}$ vs. $5.94 \mathrm{nmol} / \mathrm{mg} \pm 0.43 \mathrm{nmol} / \mathrm{mg} ; \mathrm{p}<0.001), 15(2.81 \pm 0.31 \mathrm{nmol} / \mathrm{mg}$ vs. $7.96 \pm 0.79 \mathrm{nmol} / \mathrm{mg} ; \mathrm{p}<0.001), 30 \mathrm{~min}$. $(3.39 \pm 0.32 \mathrm{nmol} / \mathrm{mg}$ vs. $9.89 \mathrm{nmol} /$ $\mathrm{mg} \pm 0.07 \mathrm{nmol} / \mathrm{mg} ; \mathrm{p}<0.001)$ and $60 \mathrm{~min}$. (3.85 $\pm 0.63 \mathrm{nmol} / \mathrm{mg}$ vs. $11.51 \mathrm{nmol} / \mathrm{mg} \pm 0.94 \mathrm{nmol} / \mathrm{mg} ; \mathrm{p}<0.001)$ compared to BSA solution without supplements. Using seperate substances at concentrations of $0.106 \mathrm{mM} \mathrm{2-oxo-glutarate} \mathrm{showed} \mathrm{a} \mathrm{significant} \mathrm{reduction} \mathrm{of} \mathrm{carbonyl} \mathrm{proteins} \mathrm{after} 2 \mathrm{~min}$. (48.5\%), $15 \mathrm{~min}$. (52.3\%), 30 min. (54.6\%) and $60 \mathrm{~min}$. (54.7\%) incubation with cigarette smoke, vitamin C: 2 min. (41,4\%), 15 min. (41.8\%), 30 min. (42.7\%) and 60 min. (45.0\%). 5-HMF: 2 (13.8\%), 15 (12.3\%), $30(7.8 \%)$ and $60 \mathrm{~min} .(10.9 \%)$.
\end{abstract}

Conclusion: In vivo study in smokers and in vitro studies showed a significant reduction of oxidatively modified proteins in the presence of a combined supplement mixture containing 2-oxoglutarate/ascorbic acid/5-hydroxy-methyl-furfur-aldehyde/carnosine.

\section{Introduction}

Tobacco smoking contains many toxic, carcinogenic and mutagenic chemicals, as well as stable and unstable free radicals [1].

The formation of smoke from a burning cigarette depends on a series of mechanisms, including the generation of by pyrolysis and combustion, aerosol formation, and physical mass transfer processes products [2]. It is known that cigarette smoking leads to various diseases because of the free radicals it contains. Additionally, it could be demonstrated that parameters like total antioxidant status (TAS), vitamin $\mathrm{C}$ and vitamin $\mathrm{E}$ were significantly higher in the non-smoker group than in the smoker group and levels of total oxidant status (TOS) and oxidative stress index (OSI) were higher in the smokers [1].
Exposure of human plasma to gas phase and whole cigarette smoke initiate or promote directly oxidative modifications of proteins, lipids, carbohydrates and DNA by about 4000 chemicals including free radicals, reactive oxygen and nitrogen species (RONS) and saturated and unsaturated aldehydes [3-6].

This generally leads to various degenerative pulmonary and cardiovascular diseases like bronchitis, emphysema, myocardial

Correspondence to: Ralf Herwig, Department of Urology, German Medical Center, Dubai, Men's Health Clinic, Vienna, Austria, E-mail: dr.ralf.herwig@ gmail.com

Received: April 02, 2018; Accepted: April 26, 2018; Published: April 30, 2018 
infarction, reduced sperm count and chronic inflammation as well as lung cancer and other malignancies $[7,8]$. Chronic inflammation activates a variety of inflammatory cells, which induce and activate several enzymes like nitric oxide synthase, myeloperoxidase, NADPH oxidase and eosinophil peroxidase. These enzymes produce high concentrations of free radicals and oxidants including superoxide anion $\left(\mathrm{O}_{2}^{*}\right)$, nitric oxides $\left(\mathrm{NO}_{\mathrm{x}}\right)$, hydrogen peroxides and hypochlorous acid, which itself reacts to a more potent oxidizing, nitrating and deaminating reagent called peroxynitrite (ONOO-) [9]. This species is able to damage DNA, RNS, lipids and proteins leading to increases mutations and altered functions of enzymes and proteins, like activation of oncogene products and inhibition of tumor-supressor proteins [5,10-12].

Many studies have shown that increased concentrations of modified proteins are measured in inflamed tissues, such as plasma of lung cancer patients and cigarette smokers [13]. Oxidative damage of proteins of human plasma like albumin and degradation of microsomal proteins in pig lung, heart and liver caused mostly by the aqueous tar phase of cigarette smoke, as evidenced by the measurement of carbonyl proteins, was completely inhibited by the water soluble ascorbic acid and only partially by glutathione, but not by other antioxidants including superoxide dismutase (SOD), catalase (CAT), vitamine E and $b$-carotene $[5,14]$. This leads to the suggestion that large doses of ascorbic acid protect smokers from oxidative damage and associated degenerative diseases. In terms of chemoprevention of oxidative damage the role and concentrations of antioxidants are yet not defined exactly. We reported about the benefits of an oral supplementation of 2-oxoglutarate and 5-hydroxy-methyl-furfurale (5-HMF) in patients for lung surgery due to non small cell lung cancer resulting in an increased exercise and energy capacity and a reduced oxidative stress by measuring the carbonyl proteins led [15]. Presently we are investigating 5-hydroxy-methyl-furfuraldehyde and 2-oxo-glutarate in phase II clinical studies as potent cytostatic and free radical scavenger acting substances $[16,17]$.

The aim of this study was to elucidate if a combination of 2-oxoglutarate/ ascorbic acid/5-hydroxy-methyl-furfuraldehyde/ carnosine protect as water soluble substances oxidative damage of proteins exposed to the gas phase of cigarette smoke.

\section{Material and methods}

2-oxoglutarate, carnosine, ascorbic acid, 5-hydroxy-methyl-furfur aldehyde, bovine serum albumine (BSA), guanidine- $\mathrm{HCl}$, butylhydroxy-toluene (BHT) were from Sigma Aldrich. Di-nitro-phenylhydrazine $(\mathrm{DNPH})$ was obtained from Fluka. alphaH $\mathrm{H}^{\circledR}$ was from HGPharma (Vienna, Austria), which contains $20 \mathrm{~mL}$ concentrate each tube. The main ingredients of alphaH $\mathrm{H}^{\star}$ are 2-oxoglutarate $(69 \mathrm{mM})$, ascorbic acid (40 mM), 5-hydroxy-methyl-furfuralaldehyde (4 mM) and carnosine $(1.1 \mathrm{mM})$.

\section{In vivo human plasma protein damage measurements in smokers and non-smokers}

For the in vivo measurement of carbonyl proteins in human plasma of 15 smokers ( $42.5 \pm 6.2$ years; 8 female and 7 male) and 15 nonsmokers (38.5 \pm 4.2 years; 6 female and 9 male) ELISA technique was used (K7822; Immundiagnostik AG, Bensheim, Germany). Carbonyl proteins in human plasma are expressed in $\mathrm{pmol} / \mathrm{mg}$ protein.

Samples containing protein are reacted with DNPH. Then the non-protein constituents and unconjugated DNPH are separated by ultracentrifugation. The proteins are adsorbed to an ELISA plate and incubated with anti-DNPH antibody followed by antibody-linked horseradish peroxidase. Absorbances are related to a standard curve prepared with oxidized serum albumin. The carbonyl protein content is calculated from the estimated carbonyl concentration and the total protein content of the sample. For this reason, a parallel determination of the protein content with the BCA protein kit is required (Pierce, USA).

\section{In vivo human erythrocyte protein damage measurements in smokers and non-smokers}

Protein carbonyls in the erythrocyte protein fraction of the same 15 smokers and 15 non-smokers were measured with the Levine et al. method (18). After blood collection and re-movement of the plasma erythrocytes are washed in $0.01 \mathrm{M}$ phosphate buffered saline (equal volume) and centrifuged $\left(4^{\circ} \mathrm{C}, 10 \mathrm{~min} ., 2000 \mathrm{rpm}\right)$. This step was repeated 3 times. Adding the same volume of cold water as to the erythrocyte volume was used to lyse erythrocytes. After centrifugation of lysed cells $\left(4^{\circ} \mathrm{C}, 10 \mathrm{~min} .11000 \mathrm{rpm}\right)$ the supernatant was precipitated with cold $20 \%$ TCA solution. The precipitate was resolved in 0.01 $\mathrm{M}$ phosphate buffered saline $\mathrm{pH}=7$ after additional centrifugation step $\left(4^{\circ} \mathrm{C}, 10 \mathrm{~min} ., 6000 \mathrm{rpm}\right)$. Protein was measured with the BCA technique (BCA assay, Pierce, USA). Carbonyl protein content was measured according to Levine et al (16) as described above. Protein carbonyl data are expressed in $\mathrm{nmol} / \mathrm{mg}$ protein.

\section{Supplementation study of smokers with 2-oxoglutarate/ vitamin C/5-hydroxy-methyl-furfur-aldehyde/carnosine}

Supplementation study was done with 10 smokers $(42.5 \pm 6.2$ years; 8 female and 7 male; 8 -12 cigarettes per day) in a double blind placebo crossover study. After a wash out phase of 2 weeks in which no supplementation of any vitamin took place, blood was collected and 10 persons started with the drinking of 2-oxo-glutarate/vitamin $\mathrm{C} / 5-\mathrm{HMF} /$ carnosine $(20 \mathrm{~mL}$ concentrate diluted in $150-200 \mathrm{~mL}$ water) twice a day (morning and afternoon). After 2 and after 4 weeks blood was collected from these 10 persons and additionally from 10 persons, which took no antioxidative supplementation. After 2 weeks wash out phase the groups changed supplementation and again after 2 and 4 weeks was collected.

All human blood samples are centrifuged at $4^{\circ} \mathrm{C}, 10 \mathrm{~min}$. at 2000 rpm and obtained plasma are stored at $-70^{\circ} \mathrm{C}$ until measurements. All in vivo formed carbonyl proteins are measured with the ELISA technique (K7822; Immundiagnostik AG, Bensheim, Germany).

\section{In vitro protein damage measurements by cigarette smoke radicals}

In vitro protein damage on BSA protein (= control measurement) by cigarette smoke was assessed by using following setup: $50 \mathrm{mg} / \mathrm{mL}$ bovine serum albumin (BSA) was dissolved in phosphate buffered saline. $4 \mathrm{~mL}$ of BSA solution was transferred in a suction bottle, which was connected to a water pump. Before smoking, two $100 \mu \mathrm{L}$ aliquots of BSA-solution were diluted with $1150 \mu \mathrm{L} 10 \mathrm{mM}$ PBS pH 7.4 containing $40 \mu \mathrm{M}$ BHT to obtain a $4 \mathrm{mg} / \mathrm{mL}$ BSA solution. $1 \mathrm{mg}$ of protein was precipitated by pipetting $250 \mu \mathrm{L}$ of the $4 \mathrm{mg} / \mathrm{mL}$ protein solution with $250 \mu \mathrm{L} 20 \%$ trichloric acid (TCA) solution. After smoking within 2 minutes further aliquots were diluted and precipitated with TCA. The glass was closed and incubated at $37^{\circ} \mathrm{C}$. After 15,30 and 60 minutes aliquots were taken out, diluted and precipitated. All precipitated samples were centrifuged at $5000 \mathrm{~g}$ for 3 minutes and the supernatant 
was removed. Pellets were dissolved in $10 \mathrm{mM}$ DNPH containing $6 \mathrm{M}$ guanidine $\mathrm{pH} 2.5$ and incubated for 45 minutes at room temperature. Protein damage was measured spectro-photometically with the protein carbonyl assay according to Levine et al. (Levine RL, Williams JA, Stadman ER, Shacter E. Carbonyl assays for determination of oxidatively modified proteins. Methods Enzymol. 1994; 233:346-57). Protein carbonyl data are expressed in $\mathrm{nmol} / \mathrm{mg}$.

$0.106 \mathrm{mM}$ concentrations of 2-oxo-ketoglutarate, $0.106 \mathrm{mM}$ 5 -HMF or $0.106 \mathrm{mM}$ ascorbic acid alone or in combination $(0.069 \mathrm{mM}$ 2-oxo-glutarate, $0.004 \mathrm{mM}$ 5-hydroxy-2-furalaldehyde and $0.04 \mathrm{mM}$ ascorbic) were dissolved in the BSA solution and protein carbonyl content before and after 2, 15, 30 and $60 \mathrm{~min}$. was estimated.

\section{Statistics}

Statistical significance was defined as $\mathrm{p}<0.05$. For comparison of patient and reference group the unpaired t-test was used for numerical variables, and the Chi-squared test for categorical variables. Students t-test was used to compare measure scores, controlling for demographics that differed significantly between patient and reference group.

Statistical analysis was performed using IBM" SPSS software 24.0, SPSS Inc., Chicago, IL, USA.

\section{Results}

In vivo human plasma and erythrocyte protein damage measurements between smokers and non-smokers

We have measured the carbonyl protein content of smokers to nonsmokers with an ELISA (Immundiagnostik AG, Bensheim). As shown in Figure 1 there was a significant difference between smokers and nonsmokers ( $448 \pm 223 \mathrm{pmol} / \mathrm{mg} \mathrm{n}=15$ vs. $191 \pm 40 \mathrm{pmol} / \mathrm{mg} ; \mathrm{n}=15 ; \mathrm{p}<0.02)$.

Additionally, we have precipitated protein from erythrocytes and compared it with the spectro-photometically measurement according to Levine et al. A significant increase of protein carbonyls is obtained also in smokers $(26.8 \pm 12.9 \mathrm{nmol} / \mathrm{mg}, \mathrm{n}=15)$ and non-smokers $(12.1 \pm 0.3 \mathrm{nmol} / \mathrm{mg} ; \mathrm{n}=15 ; \mathrm{p}<0.001)$, as shown in Figure 2 .

Supplementation study of 2-oxoglutarate/vitamin C/5hydroxy-methyl-furfur-aldehyde/carnosine in smokers

To estimate any protective effect of 2-oxoglutarate/vitamin C/5Hydroxy-methyl-furfur-aldehyde/carnosine 10 smokers drank twice a day over a period of 4 weeks compared to smokers in absence of any supplementation. Carbonyl proteins measured with the ELISA technique in the smoker group drinking 2-oxoglutarate/vitaminC/5$\mathrm{HMF} /$ carnosine showed an significant increase after 2 weeks $(357 \pm 45$ $\mathrm{pmol} / \mathrm{mg}, \mathrm{n}=10$ ) whereas a significant reduction after 4 weeks supplementation compared to the begin of the study $(228 \pm 11 \mathrm{pmol} / \mathrm{mg}$, $\mathrm{n}=10$ vs. $273 \pm 55 \mathrm{pmol} / \mathrm{mg}, \mathrm{n}=10 ; \mathrm{n}<0.02$ ) was measured (Figure 3 ). No difference in the content of Carbonylproteins were obtained between the supplemented and non supplemented smoker groups after 2 weeks $(357 \pm 45 \mathrm{pmol} / \mathrm{mg}, \mathrm{n}=10 \mathrm{vs} .298 \pm 34 \mathrm{pmol} / \mathrm{mg}, \mathrm{n}=10)$. The difference in the content of carbonylproteins after 2 and 4 weeks of supplemented smokers was highly significant reduced from $357 \pm 45 \mathrm{pmol} / \mathrm{mg}$ to $228 \pm 11 \mathrm{pmol} / \mathrm{mg}(\mathrm{n}=10 ; \mathrm{p}<0.001)$. Also a significant decrease after 4 weeks supplemented smokers $(228 \pm 11 \mathrm{pmol} / \mathrm{mg}, \mathrm{n}=10)$ was estimated compared to the smokers after 4 weeks in absence of any supplements (325 $\pm 45 \mathrm{pmol} / \mathrm{mg} ; \mathrm{p}<0.001)$.

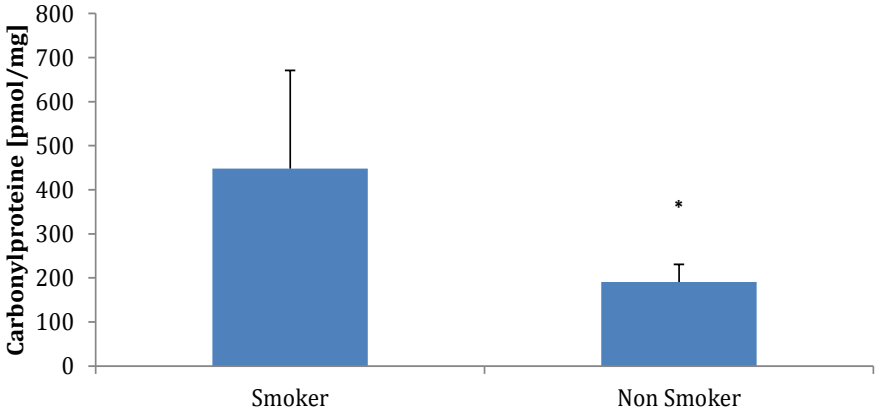

Figure 1. Comparison of plasma carbonyl proteins between smokers $(n=10)$ and nonsmokers $(\mathrm{n}=10) ; \mathrm{p}<0.02$

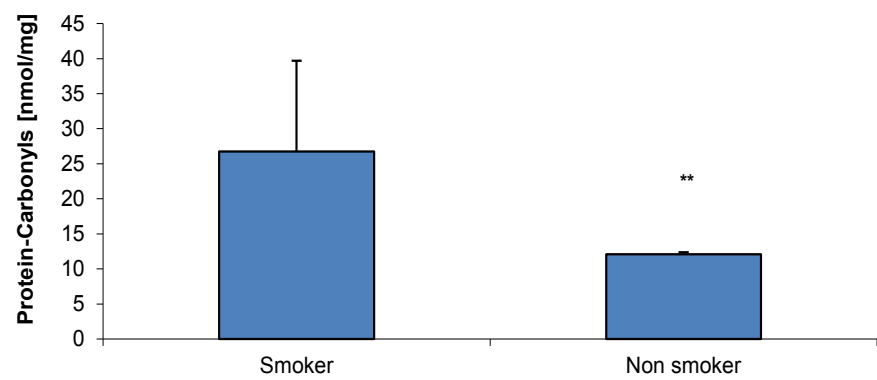

Figure 2. Comparison of erythrocyte carbonyl proteins between smokers $(\mathrm{n}=10)$ and nonsmokers $(\mathrm{n}=10) ;{ }^{* *}=$ significant effect $\mathrm{p}<0.001$

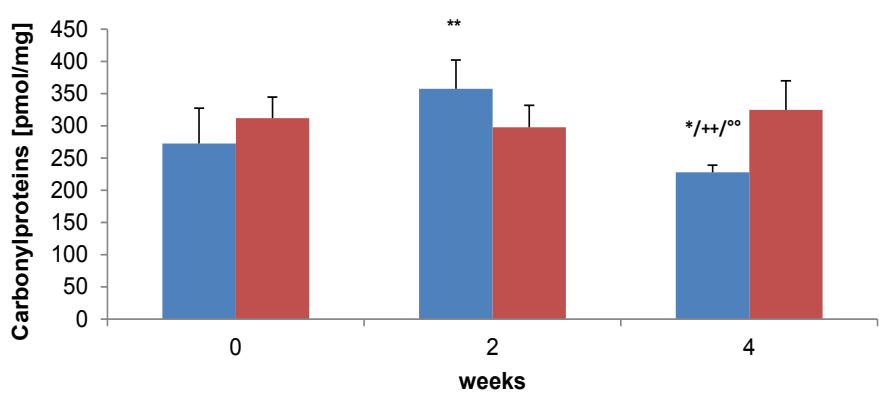

Figure 3. Comparison of plasma carbonyl proteins between smokers supplementing alphaH ${ }^{\circledR}$ (blue bars, $n=10$ ) or in absence (red bars, $n=10$ ) over 4 weeks. * Significant effect between supplemented smokers before and after 4 weeks $(\mathrm{p}<0.02)$, ** highly significant effect between supplemented smokers before and after 4 weeks $(\mathrm{p}<0.001) .{ }^{++}$Highly significant effect between supplement smokers after 2 and 4 weeks $(p<0.001)$. Highly significant effect between supplement smokers and non smokers after 4 weeks $(\mathrm{p}<0.001)$

In vitro protein damage measurements by cigarette smoke radicals in absence or presence of 2-oxoglutarate/vitamin C/5-hydroxy-methyl-furfur-aldehyde

Figure 4 shows the inhibition of carbonyl proteins of a BSA-solution in vitro with the main components e.g. $0.069 \mathrm{mM}$ 2-oxoglutarate, $0.004 \mathrm{mM} 5$-hydroxy-2-fural-aldehyde and $0.04 \mathrm{mM}$ ascorbic during exposure of cigarette smoke compared to the BSA control solution. The reduction of damaged proteins by alphaH ${ }^{\oplus}$ was $63.3 \%$ after $2(2.18 \pm 0.34$ $\mathrm{nmol} / \mathrm{mg}$ vs. $5.94 \mathrm{nmol} / \mathrm{mg} \pm 0.43 \mathrm{nmol} / \mathrm{mg} ; \mathrm{p}<0.001 ; \mathrm{n}=6), 64.7 \%$ after $15(2.81 \pm 0.31 \mathrm{nmol} / \mathrm{mg}$ vs. $7.96 \pm 0.79 \mathrm{nmol} / \mathrm{mg} ; \mathrm{p}<0.001 ; \mathrm{n}=6), 65.7 \%$ after $30(3.39 \pm 0.32 \mathrm{nmol} / \mathrm{mg}$ vs. $9.89 \mathrm{nmol} / \mathrm{mg} \pm 0.07 \mathrm{nmol} / \mathrm{mg} ; \mathrm{p}<0.001$; $\mathrm{n}=6)$ and $66.6 \%$ after 60 minutes $(3.85 \pm 0.63 \mathrm{nmol} / \mathrm{mg}$ vs. $11.51 \mathrm{nmol} /$ $\mathrm{mg} \pm 0.94 \mathrm{nmol} / \mathrm{mg} ; \mathrm{p}<0.001 ; \mathrm{n}=6$ ) compared to control BSA solution. After $15 \mathrm{~min}$. of smoking carbonyl proteins in presence of 2-oxoglutarate/vitamin C/5-HMF showed a significant increase compared to BSA in absence of 2-oxo-glutarate/vitamin C/5-HMF before smoking 


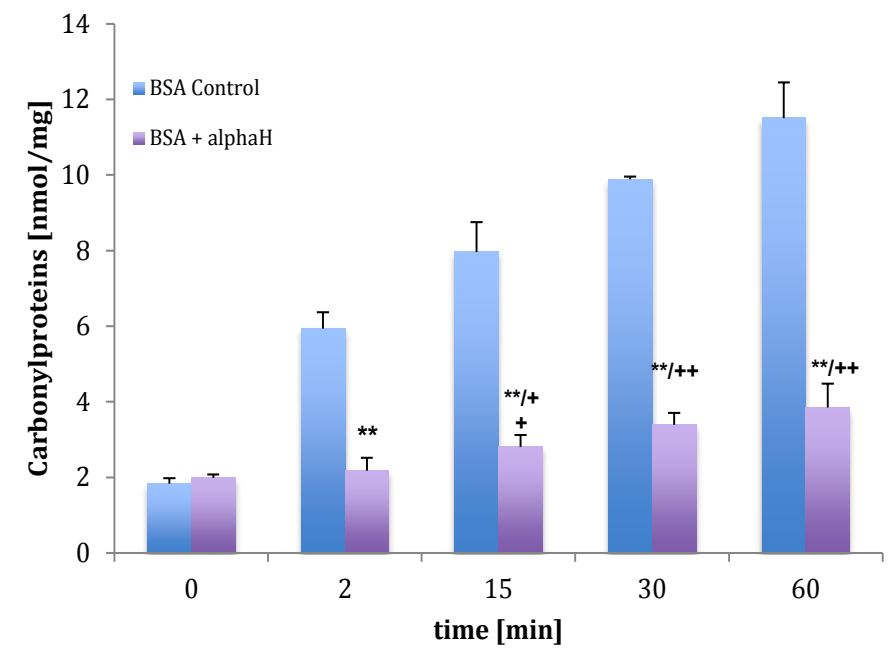

Figure 4. Comparison of carbonyl protein of BSA before and after smoke radical administration in the presence (violet bars) or absence of alphaH (blue bars). ** High significant effect between carbonyl proteins in presence and absence of alphaH $(\mathrm{p}<$ $0.001),{ }^{++}$high significant effect between carbonyl proteins before and after smoke radical administration $(\mathrm{p}<0.001)$

\section{$(1.99 \pm 0.09 \mathrm{nmol} / \mathrm{mg}$ vs. $1.83 \pm 0.15 \mathrm{nmol} / \mathrm{mg} ; \mathrm{n}=6)$.}

After 2 min. smoking the protection of 2-oxo-glutarate/vitamin $\mathrm{C} / 5$-HMF against direct radical attack on BSA was effective because no significance could be obtained compared to control BSA.

In vitro protein damage measurements by cigarette smoke radicals in absence or presence of 2-oxo-glutarate, ascorbic acid and 5-hydroxy-methyl-furfur-aldehyde

Figure 5 shows the protective oxidative damage by cigarette smoke radicals before and after incubation in the presence of 0.106 $\mathrm{mM}$ ascorbic acid, $0.106 \mathrm{mM}$ 2-oxoglutarate or $0.106 \mathrm{mM}$ 5-hydroxymethyl-furfur-aldehyde alone. Over all incubation times the carbonyl protein content of BSA in presence of all three substances decreased significant compared to the control BSA. While 5-hydroxy-methylfurfur-aldehyde showed the weakest protection, 2-oxo-glutarate and ascorbic acid more as described in Table 1 .

Over all time points 2-oxo-glutarate reduced the content of carbonyl proteins more than ascorbic acid: after $2 \mathrm{~min}$. of cigarette smoke the reduction in presence of 2-oxoglutarate was $48.5 \%(3.06 \pm 0.07 \mathrm{nmol} /$ $\mathrm{mg}$ ) versus $41.4 \%(1.85 \pm 0.1 \mathrm{nmol} / \mathrm{mg})$; after $15 \mathrm{~min} .52 .3 \%(3.80 \pm 0.22$ $\mathrm{nmol} / \mathrm{mg})$ versus $41.8 \%(4.63 \pm 0.4 \mathrm{nmol} / \mathrm{mg})$; after $30 \mathrm{~min} .54 .6 \%$ $(4.49 \pm 0.1 \mathrm{nmol} / \mathrm{mg})$ versus $42.7 \%(5.67 \pm 0.53 \mathrm{nmol} / \mathrm{mg})$ and after 60 min. $54.7 \%(5.21 \pm 0.75 \mathrm{nmol} / \mathrm{mg})$ versus $45.0 \%$ (6.33 $\pm 0.50 \mathrm{nmol} / \mathrm{mg})$.

5-hydroxy-methyl-furfur-aldehyde showed a reduction after 2 $\mathrm{min}$. of $13.8 \%(5.12 \pm 0.34 \mathrm{nmol} / \mathrm{mg})$, after $15 \mathrm{~min}$. of $12.3 \%(6.98 \pm 0.31$ $\mathrm{nmol} / \mathrm{mg})$, after $30 \mathrm{~min}$. of $7.8 \%(9.12 \pm 0.32 \mathrm{nmol} / \mathrm{mg})$ and after 60 min. of $10.9 \%(10.9 \pm 0.63 \mathrm{nmol} / \mathrm{mg})$.

\section{Discussion}

Despite many substances identified in cigarette smoke causing harmful diseases likelung cancer, oral squamous cell carcinoma (OSCC), or infertility, macula degeneration, diabetes, arteriosclerosis or bladder cancer and chronic obstructive pulmonary disease, tobacco smoke is a toxic gas-phase cocktail consisting of a broad range of organics, and free radical intermediates. The formation of smoke from a burning cigarette depends on a series of mechanisms, including the generation of toxic by pyrolysis and combustion, aerosol formation, and physical mass transfer processes. It is therefore evident from this investigation that cigarette smoke contains surface bound radicals considered harmful to the health of cigarette smokers products [2]. Oxidative stress occurs whenever the release of reactive oxygen species (ROS) exceeds endogenous antioxidant capacity [19]. Tobacco smoke contributes to an important exogenous resource of free radicals and oxidants. Due to the high responsiveness of reactive oxygen species, these substances are able to oxidize phospholipids by a chain of reactions through lipid peroxidation resulting in the formation of protein carbonyls [20]. It could be proven, that cigarette smoke leads to the formation of protein carbonyls in human plasma [21,22]. Increased carbonyl proteins as a marker of oxidative damage in a smoker population compared to an age matched non-smoker population are measured by Kapaki E et al. with a low-spectro-photometrical techinque. Therefore, the results are only slightly elevated in the smoker group. We used a sandwich ELISA in which all plasma proteins are bound to anti-IgG against plasma proteins. Using anti-DNPH-derivatized antibody, serving as reporting antibody in this new technique, we determined a more than two fold higher amount in smokers compared to a healthy aged non-smokers with a high significance. Additionally, we also detected a significant higher amount of carbonyl proteins in erythrocytes for the first time. Low fruit and vegetable intake failed to decrease to protect the generation of carbonyl proteins in smokers [23], neither did olive oil phenols [24]. We have applied a supplement combination of 2-oxoglutarate/vitamin C/ 5-hydroxy-methyl-furfur-aldehyde/ carnosine in smokers and could detect a significant reduction of the carbonyl proteins in vivo after 4 weeks compared to non-supplemented

Table 1. Calculated reduction (\%) of vitamin c, 2- oxo-glutarate and 5-HMF of carbonyl proteins in presence of smoke radicals compared to control (carbonyl proteins in presence of smoke radicals at each time point $=100 \%$ )

\begin{tabular}{|c|c|c|c|}
\hline Table 1 & \multicolumn{3}{|c|}{ Reduction of Carbonylproteins in \% } \\
\hline time [min] & $\begin{array}{c}\text { BSA+ Vitamin C } \\
(\mathbf{0 . 1 0 6 m M )}\end{array}$ & $\begin{array}{c}\text { BSA + AKG } \\
\mathbf{( 0 . 1 0 6 m M )}\end{array}$ & $\begin{array}{c}\text { BSA+ 5-HMF } \\
\mathbf{( 0 . 1 0 6 m M )}\end{array}$ \\
\hline 2 & 41,4 & 48,5 & 13,8 \\
\hline 15 & 41,8 & 52,3 & 12,3 \\
\hline 30 & 42,7 & 54,6 & 7,8 \\
\hline 60 & 45,0 & 54,7 & 10,9 \\
\hline
\end{tabular}

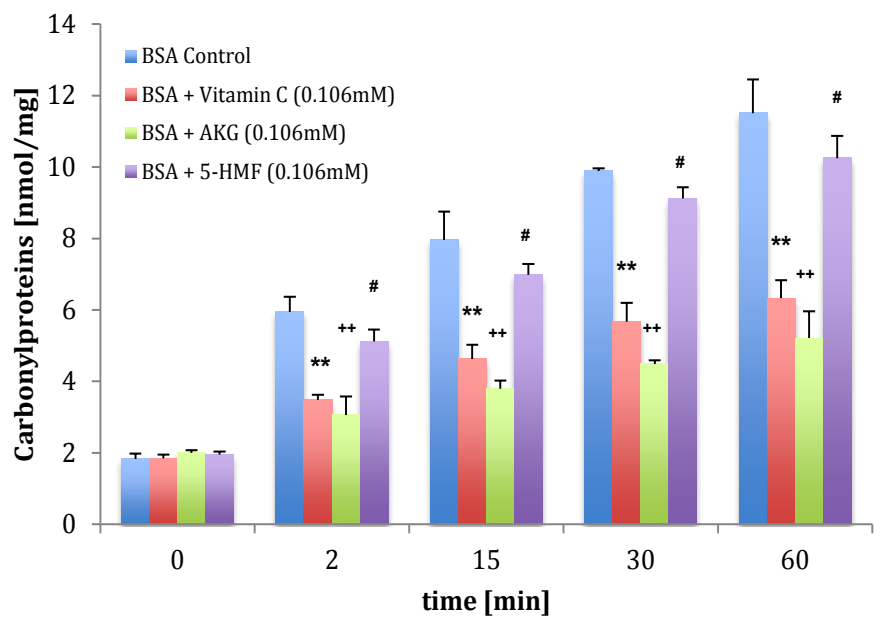

Figure 5. Comparison of carbonyl protein of BSA before and after smoke radical administration in the presence (violet bars) or absence of the main components of alphaH: vitamin c, 2-oxo-glutarate and 5-HMF. ** High significant effect between carbonyl proteins in presence and absence of $0.106 \mathrm{mM}$ vitamin $\mathrm{c}(\mathrm{p}<0.001),{ }^{++}$high significant effect between carbonyl proteins in presence and absence of $0.106 \mathrm{mM}$ 2-oxo-glutarate $(\mathrm{p}<0.001),{ }^{\#}$ significant effect in presence and absence of $0.106 \mathrm{mM} 5-\mathrm{HMF}(\mathrm{p}<0.001)$ 
Greilberger JF (2018) Combination of 2-oxoglutarate/ascorbic acid/5-hydroxy-methyl-furfur-aldehyde/carnosine inhibits protein oxidation during radical exposure of cigarette smoke

smokers using the afore-mentioned ELISA technique. Interestingly, after 2 weeks of supplementation we found a higher content of carbonyl proteins in plasma, which might be a shift of preformed carbonyl proteins solved from the tissue moving into the blood stream.

Vitamin C is well known to react directly with free radicals and therefore prevent oxidative modification on proteins in vivo (Dal and Sigrist, 2016, \#8136). But during this reaction it is radicalized itself. Therefore, to recover vitamin $\mathrm{C}$ from this reaction, 2-oxo-glutarate, 5-hydroxy-methyl-furfur-aldehyde and carnosine were added, which are known substances in reducing radicals like peroxides $\left(\mathrm{H}_{2} \mathrm{O}_{2}\right.$, $\left.\mathrm{ONOO}^{-}\right)[5,6,25,26]$ and could therefore restore the anti-oxidative capacity of vitamin C. In the in-vitro study we compared the reaction of these substances on cigarette smoke incubated BSA under equimolare concentrations. The most protective effect from oxidation could be reached by 2 -oxoglutarate, compared to vitamin $\mathrm{C}$, the lowest impact was determined using 5-hydroxy-methyl-furfur-aldehyde alone. Interrestingly, the highest protection against oxidation was reached by combining all four substances, as provided in alphaH ${ }^{\varpi}$ and could highly significantly decrease the amount of carbonyl proteins by 3 -fold or $66 \%$, compared to any single substance measured. Moreover, the generation of carbonyl proteins after smoking was nearly stopped. This may results in a synergistic antioxidative action.

In summary, tobacco smoke contains many toxic substances and free radicals. This observation shows that a high protective effect of antioxidative substances, as combined in alphaH, against free radical production from cigarette smoke can be reached in vitro and in vivo and implies that future studies investigating the protective effect of antioxidant consumption on several disorders should also consider smoking status. Thus, further studies are needed to better elucidate the benefit of antioxidant nutrients and diseases influenced or caused by free radicals.

\section{References}

1. Karademirci M, Kutlu R, Kilinc I (2017) Relationship between smoking and total antioxidant status, total oxidant status, oxidative stress index, vit C, vit E. Clin Respir $J$. [Crossref]

2. Jebet A, Kibet J, Ombaka L, Kinyanjui T (2017) Surface bound radicals, char yield and particulate size from the burning of tobacco cigarette. Chem Cent J 11: 79.

3. Dube MF, Green CF (1982) Methods of collection of smoke for analytical purposes. Recent Advances in Tobacco Science 8: 42-102.

4. Schumacher JN, Green CR, Best FW, Newell FW (1977) Smoke composition. An extensive investigation of the water-soluble portion of cigarette smoke. J Agric Food Chem 25: 310-320.

5. Panda K, Chattopadhyay R, Chattopadhyay D, Chatterjee ID (2001) Cigarette smokeinduced protein oxidation and proteolysis is exclusively caused by its tar phase: prevention by vitamin C. Toxicol Lett 123: 21-32. [Crossref]

6. Pryor WA, Prier DG, Church DF (1983) Electron-spin resonance study of mainstream and sidestream cigarette smoke: nature of the free radicals in gas-phase smoke and in cigarette tar. Environ Health Perspect 47: 345-355. [Crossref]

7. Ohshima H, Tatemichi M, Sawa T (2003) Chemical basis of inflammation-induced carcinogenesis. Arch Biochem Biophys 417: 3-11. [Crossref]

8. Adewoyin M, Ibrahim M, Roszaman R, Isa MLM, Alewi NAM, et al. (20147) Male infertility: The effect of natural antioxidants and phytocompounds on seminal oxidative stress. Diseases 5: 9. [Crossref]

9. Beckman JS, Koppenol WH (1996) Nitric oxide, superoxide, and peroxynitrite: the good, the bad, and ugly. Am J Physiol 271: C1424-1437. [Crossref]

10. Ducrocg C, Blanchard B, Pignatelli B, Oshima H (1999) Peroxynitrite: An endogenous oxidizing and nitrating agent. Cell Mol Life Science 55: 1068-1077. [Crossref]

11. Ischiropoulos H (1998) Biological tyrosine nitration: a pathophysiological function of nitric oxide and reactive oxygen species. Arch Biochem Biophys 356: 1-11. [Crossref]

12. Szabó C, Ohshima H (1997) DNA damage induced by peroxynitrite: subsequent biological effects. Nitric Oxide 1: 373-385. [Crossref]

13. Vineis P, Alavanja M, Buffler P, Fontham E, Franceschi S, et al. (2004) Tobacco and cancer: recent epidemiological evidence. academic.oup.com.

14. Panda K, Chattopadhyay R, Chattopadhyay DJ, Chatterjee IB (2000) Vitamin C prevents cigarette smoke-induced oxidative damage in vivo. Free Radic Biol Med 29 115-124. [Crossref]

15. Maier A, Matzi V, Lindemann J, Boessner T, Oettl K, et al. (2006) Metabolic effects of oral supplementation of Alpha-Ketoglutaric acid and 5-Hydroxy-methyl-furfural in preoperative nutritional support of lung surgery. Eur Surg Supplement 209: 31.

16. Michail K, Matzi V, Maier A, Herwig R, Greilberger J, et al. (2007) Hydroxymethylfurfural: an enemy or a friendly xenobiotic? A bioanalytical approach. Anal Bioanal Chem 387: 2801-2814. [Crossref]

17. Herwig R. Pilotstudie KARAL-Monochemotherapien. Austria: 393221 B.

18. Levine RL, Williams JA, Stadtman ER, Shacter E (1994) Carbonyl assays for determination of oxidatively modified proteins. Methods Enzymol 233: 346-357. [Crossref]

19. Niemann B, Rohrbach S, Miller MR, Newby DE, Fuster V (2017) Oxidative stress and cardiovascular risk: Obesity, Diabetes, smoking, and pollution: Part 3 of a 3-part series. $J$ Am Coll Cardiol 70: 230-251. [Crossref]

20. Shin JM, Park JH, Kim HJ, Park IH, Lee HM (2017) Cigarette smoke extract increases vascular endothelial growth factor production. Am J Rhinol Allergy 31: 78-84. [Crossref]

21. Reznick AZ, Cross CE, Hu ML, Suzuki YJ, Khwaja S (1992) Modification of plasma proteins by cigarette smoke as measured by protein carbonyl formation. Biochem $J 286$ 607-611. [Crossref]

22. Marangon, K, Devaraj S, Jialal I (1999) Measurement of protein carbonyls in plasma of smokers and in oxidized LDL by an ELISA. Clin Chem 45: 577-578. [Crossref]

23. Jacob RA, Aiello GM, Stephensen CB, Blumberg JB, Milbury PE (2003) Moderate antioxidant supplementation has no effect on biomarkers of oxidant damage in healthy men with low fruit and vegetable intakes. $J$ Nutr 133: 740-743. [Crossref]

24. Moschandreas J, Vissers MN, Wiseman S, van Putte KP, Kafatos A (2002) Extra virgin olive oil phenols and markers of oxidation in Greek smokers: a randomized cross-over study. Eur J Clin Nutr 56: 1024-1029. [Crossref]

25. Matzi V, Lindenmann J, Muench A, Greilberger J, Juan H, et al. (2007) The impact of preoperative micronutrient supplementation in lung surgery. A prospective randomized trial of oral supplementation of combined alpha-ketoglutaric acid and 5-hydroxymethylfurfural. Eur J Cardiothorac Surg 32: 776-782. [Crossref]

26. Babizhayev MA (2014) The detox strategy in smoking comprising nutraceutical formulas of non-hydrolyzed carnosine or carcinine used to protect human health. Hum Exp Toxicol 33: 284-316. [Crossref]

Copyright: (C2018 Greilberger JF. This is an open-access article distributed under the terms of the Creative Commons Attribution License, which permits unrestricted use, distribution, and reproduction in any medium, provided the original author and source are credited. 